\title{
Macroeconomic Policies and Social Inclusion in the Developing World
}

\author{
Zakia Batool $^{1-2}$ \& Arshad Ali Bhatti*1 \\ 1. International Institute of Islamic Economics, International Islamic University, Islamabad, Pakistan. \\ 2. Department of Economics, National University of Modern Languages (NUML), Islamabad, Pakistan.
}

Received: September 09, 2019

Accepted: November 27, 2020

Published: December 15, 2020

\begin{abstract}
Many in the developing world face social exclusion and discrimination, preventing them from actively participating in society itself. Sound macroeconomic policies with a focus on stabilizing the price level and social outcomes can help to achieve social justice for marginalized people. This study empirically examines the impact of macroeconomic policies on social inclusion, considering specifically the coordination among them in promoting that social inclusion. It deals primarily with pure non-income dimensions of social inclusion such as education, and health, etc. Using annual panel data of 51 developing countries for the period 1995-2017 this study employs state-of-the-art panel data estimation methods - pooled estimation, fixed-effect, and random-effect models. To check for robustness and to handle the problem of endogeneity, the 2SLS technique has also been used. This study argues that a well-designed macroeconomic policy framework can do much more than just achieve economic goals. Results suggest that fiscal and monetary policy, through resource mobilization, can play a significant and positive role in promoting social inclusion. However, these fiscal and monetary policy actions are not independent; thus, a policy mix is required to achieve the target of an inclusive society.
\end{abstract}

Keywords: Monetary Policy, Government Spending, Tax Revenue, Social Inclusion, Institutional Quality, PCA, Panel Data.

\section{Introduction}

Inclusive growth is a phenomenon that is getting much attention in today's world because it stresses growth with equality. One of the dimensions of inclusive growth is social inclusion that focuses on polishing the abilities of individuals and empowers them so that they could actively take part in social and economic activities and enjoy higher living standards. A society is termed as inclusive if all individuals get equal opportunities to thrive in society and make a good living for themselves. In short, social inclusion implies a culture where everyone in society is treated fairly and feels valued. Individuals in society get equal opportunities to contribute to society if they are given equal access to improve their productivity through education and health etc.

According to United Nations Educational, Scientific and Cultural Organization (UNESCO), social inclusion is all about equality, freedom, social justice, having tolerance, and acceptance of diversity (UNESCO, 2012); whereas the World Bank's (2013) definition emphasizes social inclusion as a process that improves the ability, opportunity, and dignity of socially disadvantaged people. The socially excluded individuals are those who face discrimination 
based on race, religion, occupational status, location, or gender thus inclusiveness of the society demands the provision of equal opportunities to everyone irrespective of their ascribed identity. Social inclusion highlights the fact that inequality exists beyond income distribution. Klasen (2010) emphasizes both income and the non-income dimension of well-being and explains that the non-income dimension includes the reduction of inequality in education, health, and social protection. In low and middle-income countries, secondary school enrolment is 62.3 percent and 92.7 percent in high-income countries. On the other hand, easy access to health care services creates a positive externality in society and improves the efficiency of the labour force. Therefore, a better health-care system is necessary for both welfare and economic growth.

Designing sound macroeconomic policies with a focus on stabilizing the price level and social outcomes can help to achieve social justice to the marginalized people and thus improve social inclusion in developing countries. Tax and government spending are used to correct inequality in income distribution but a comprehensive use of fiscal instruments can also ensure an inclusive society by correcting the inequality in the non-income dimension of well-being. Allocation of social spending within the education and health sectors helps the socially neglected groups to participate in economic activities. Islam (2000) argues that a well-designed fiscal policy has the potential to raise the capabilities of disadvantaged sections of the economy through the provision of public goods. Monetary policy can also affect social welfare through different channels. Monetary policy through the inflation channel reduces the real value of wages and hurts the underprivileged section more and discourages investment in human capital whereas Mattenheim and Lima (2014) argue that monetary policy, through credit and interest rate channels, improves social inclusion. The expansionary monetary policy makes the cost of money cheaper for small entrepreneurs including female entrepreneurs, and thus improves social inclusion. However, the extent of the predetermined fiscal deficit requires the coordination of monetary and fiscal policy. Following the above discussion, this study considering purely non-income dimensions of social inclusion constructs an index of social inclusion and analyses the effect of fiscal and monetary policy to ensure social inclusion in developing countries. This paper analyses how the coordination of macroeconomic policies ensures social inclusion that would help the policymakers in developing countries to devise a policy mix that would enhance the participation of the socially excluded groups.

\section{2. $\quad$ Related Literature}

Different studies have highlighted the need of making a society inclusive that allows individuals to have access to institutions and resources. The notion of social inclusion surfaced in response to the welfare crisis in Europe that diverted the attention of policymakers and politicians towards social disadvantages (Rawal, 2008). Many researchers have tried to define social inclusion. However, the literature lacks a formal and unanimously accepted definition of social inclusion. Numerous studies have used the word social exclusion and social inclusion alternatively. O'Brien and Penna (2007) are of the view that social exclusion is all about the problems that get in the way of social stability. Thus, social exclusion highlights the social barriers and draw the attention of policymakers to make a society where all people should have access to everything (Atkinson, 1998). Oxoby (2009) in his study defines social inclusion as access to opportunities that help individuals to attain capabilities and affects their decision of investment in human and social capital. Furthermore, he explains that social inclusion requires equal access to employment, housing, social protection, health, and education. Felder (2018) explains that the most crucial aspect of inclusion is freedom: the ability of individuals to set and exert towards goals, granted social acceptance and security whereas Wang and Naveed 
(2019) define social inclusion as a process of achieving equality. Aslam et al. (2020) argue that social inclusion along with institutional quality and digital inclusion leads to inclusive growth.

Social protection of an extremely poor section of the economy is a necessary element to make society inclusive. The provision of social-safety nets helps in eradicating poverty and makes the opportunities available to the extremely poor. Drucza (2016) is of the view that cash transfers to the poor section of the economy facilitate social inclusion. Avramov (2003) argues that social inclusion re-establishes social bonds by providing individuals access to social protection, income, and public institutions. Along with social security, many studies emphasize that access to education and health underpins social inclusion and makes the underprivileged group of society able to participate in social and economic activities. Both physical and mental health is necessary for individuals to reach out to opportunities and participate in community life. Tangcharoensathien et al. (2018) argue that the well-being of the vulnerable section is important for social inclusion because an unhealthy population lacks capabilities and contributes to social exclusion. On the other hand, analysing the role of education, Gradstein and Justman (2002) examine that provision of educational services reduces the social distance and leads to a cohesive economy and well-being.

Equality of opportunities across gender is also an important aspect of the discussion on economic forums that endorse social inclusion. The Sustainable Development Goals (SDGs) also stress gender equality and promote women's empowerment to achieve inclusive development. In many developing countries, due to socio-cultural norms, women face hurdles to achieve their educational and career goals. Crotti et al. (2020) highlight that only 18 percent of labour income goes to female workers. According to the World Bank (2011), 34 percent of women in Malawi lack the power to spend their income. The report presented by Wan and Zhuang (2015) explores that the gap in education across gender is high in Pakistan as compared to other Asian and Pacific countries.

Fiscal policy through the provision of public goods and services can persuade the participation of weaker section of the economy, influences social welfare, and promotes social cohesion (Ceano-Vivas et al., 2014). De-la-Brière and Rawlings (2006) examine that conditional cash transfers to women and poor families effectively increase human capital and thus foster social inclusion. We cannot ignore the fact that without the support of the public sector, health services will be affordable to only the rich class (Akram \& Khan, 2007). The more the population has access to better health services, the more valued will be the human capital. In this study, the mortality rate is used to measure the condition of health in the economy. Furthermore, the government's spending on R\&D and education is also very productive for the economy (European Commission, 2004) and thus enhances the access of masses to social and economic opportunities. Public investment in the human capital of the poor segment leads to both social protection and human development (World Bank, 2006).

Monetary channels also play a role to make society inclusive. Microfinance programs and social services including unemployment insurance and social security reduce the disparity between a privileged and disadvantaged section of the economy (Monzini, 2008). Monetary policy through its price and credit channel affects social welfare. Studies have shown that monetary policy, through its interaction with fiscal and labour market policy and by influencing price stability, affects the overall welfare gain (Ravenna \& Walsh, 2010). However, different studies have confirmed that the government's decision about the taxes and revenue affects the monetary policy decision hence setting any policy actions the effects of other policies should 
also be borne in mind (Afonso et al., 2019).

Overall, past studies in the literature theoretically discuss the social content of macroeconomic policies but the literature is still scarce with regards to empirical evidence on how macroeconomic policies promote social inclusion. This study takes up this issue and aims to fill the gap in the literature by developing a measure of social inclusion for developing countries and assesses the interactive role of macroeconomic policies on social inclusion.

\section{Conceptual and Theoretical Framework}

Social inclusion focuses on the social welfare of individuals and their access to social goods like education, health, etc. This concept emerged because inequality exists beyond income. According to World Bank (2013), social inclusion is about working on those factors that help the disadvantaged group of the society to improve their ability, dignity, and opportunity so that they could play a part in society. Therefore, all the individuals in the economy shall be provided with resources and services so that they all could be equally capable to ensure social inclusion. It includes access to education, health, social security, gender equity. It is a fact that a person with an educational degree will have a better earning opportunity than an uneducated person because education and knowledge help in increasing the skills and productivity of the individual and consequently accelerates economic growth. Many studies have used the school enrolment ratio at the primary and secondary levels to measure access to education. The second indicator of social inclusion is the access of the population to health services. The more the population has access to better health services, the more valued will be the human capital. In this study, the mortality rate is used to measure the condition of health in the economy.

The third indicator of social inclusion is social security. The provision of social-safety nets helps individuals to come out of the virtuous circle of poverty Public social protection expenditure as a percentage of GDP is used as an indicator of social protection. The fourth indicator of social inclusion is gender equity. When it comes to the inclusiveness of society, there should not be any discrimination among females and males. Inclusiveness requires participation from maximum individuals regardless of their gender and the distribution of the growth benefits should be reached to every person irrespective of their gender. Since inequality across gender mainly arises at their school-going age, that is, if a woman is made deprived of education facilities then automatically her participation and earnings will be affected as well, thus an index of gender parity (primary school enrolment) is used to measure gender equity.

Fiscal and monetary policy with a focus on stabilizing the price level and social outcomes affects social inclusion. Fiscal policy through the provision of social goods and services helps the socially neglected group to come out of the vicious circle of social exclusion. Provision of education and health services, by increasing their productivity, allows the marginalized people to participate in the growth process. On the other hand, monetary policy through the inflation channel affects social welfare while expansionary monetary policy by lowering interest rate encourages investment in all sectors including education and health. In a policy framework, changes in fiscal policy are expected to affect inflation and thereby on the interest rate. Therefore, while setting the interest rates, the central bank has to keep into consideration the effect of fiscal policy on aggregate demand and thus inflation. Thus, fiscal policy influences the efficacy of monetary policy by affecting inflation. Consequently, fiscal, and monetary policy actions are not independent, and keeping in view this fact, the current study analyses the interactive role of macroeconomic policies on social inclusion. 


\subsection{Methodology to Construct a Composite Index}

Various approaches are available in the literature that is used for the derivation of a onedimensional index. The construction of any composite index involves various steps. The first step is to define the notion that a study wants to measure. In this step, the focus is to define the dimensions of the concept and possible indicators of each dimension. In the previous section, the concepts of social inclusion and its indicators have been discussed. Generally, these indicators are expected to be correlated with each other but the objective is to select the independent indicators. Salzman (2003) suggests that indicators having low correlations must be selected so that redundancy could be reduced. Multiple correspondence analysis, principal component (PCA hereafter), or the correlation analysis are frequently used methods to choose the most relevant indicators and their weights.

The application of PCA to extract appropriate weights for each indicator requires a few prerequisites. PCA requires a sufficiently large sample size and the rule of thumb is to have a sample size of at least ten times more than the number of items used for the construction of the index. PCA does not give any useful information if most of the variables have correlations closer to zero. For this, we can apply correlation and test the significance of the correlation value that whether it is significantly different from zero or not (Mooi et al., 2018). In short, PCA requires a sufficient level of correlations among indicators. To check this condition, this study uses a pairwise correlation and Bonferroni-adjusted level of significance that helps to avoid the risk of having a type-I error. Its calculation requires a division of level of significance by the number of tests. Mooi et al. (2018) explain that in addition to the correlation test, KaiserMeyer-Olkin (KMO hereafter) statistics can be used to check sampling adequacy; its value ranges between 0 and 1. David and Jacobs (2014) explain that KMO talks about whether applying PCA is appropriate or not and suggested that a KMO value greater than 0.5 is considered ideal. Kiaser (1974) designed the threshold levels for KMO.

Before applying PCA to extract weights, one of the main steps is to normalize the indicators to make them unitless because different indicators are measured in different units. Standardization helps in assessing the commonality of each variable. To do so, different techniques, for example, min-max transformation, ranking, z-score, etc., are used. This study uses a min-max transformation to make unit free variables within the range of zero and a hundred. Mathematically, if we have a set of $n$ variables that are supposed to be correlated, PCA is used to develop uncorrelated components such that each of the components is a linear combination of the variables in the set.

$$
\begin{aligned}
& \mathrm{P}_{1}=\alpha_{11}\left[\frac{x_{1}-\overline{x_{1}}}{s_{1}}\right]+\alpha_{12}\left[\frac{x_{2}-\overline{x_{2}}}{s_{2}}\right]+\ldots \ldots \ldots \ldots \ldots \ldots \ldots \ldots+\alpha_{1 n}\left[\frac{x_{n}-\overline{x_{n}}}{s_{n}}\right] \\
& \mathrm{P}_{2}=\alpha_{21}\left[\frac{x_{1}-\overline{x_{1}}}{s_{1}}\right]+\alpha_{22}\left[\frac{x_{2}-\overline{x_{2}}}{s_{2}}\right]+\ldots \ldots \ldots \ldots \ldots \ldots \ldots \ldots+\alpha_{2 n}\left[\frac{x_{n}-\overline{x_{n}}}{s_{n}}\right] \\
& \mathrm{P}_{\mathrm{k}}=\alpha_{k 1}\left[\frac{x_{1}-\overline{x_{1}}}{s_{1}}\right]+\alpha_{k 2}\left[\frac{x_{2}-\overline{x_{2}}}{s_{2}}\right]+\ldots \ldots \ldots \ldots \ldots \ldots \ldots \ldots \ldots+\alpha_{k n}\left[\frac{x_{n}-\overline{x_{n}}}{s_{n}}\right]
\end{aligned}
$$

Where $\alpha$ 's are the weights that are assigned to $k$ principal components and " $s$ " is the standard deviation. Here a constraint is put on the weights that $\alpha \alpha \stackrel{\prime}{=} 1$, that is, squared weights must sum to one. The weight assigned to each component depends on the eigenvectors of the covariance matrix. The variance of each of the principal components is calculated by using the 
eigenvalue of eigenvectors and according to the Kaiser Criterion (Kaiser, 1960) -- Latent-root Criterion. We extract all the components having an eigenvalue greater than one.

After applying PCA, the components give relative weight for each of the indicators and the next step is aggregation. The most widely used aggregation method is the linear sum of weighted normalized indicators. Nardo et al. (2005) are of the view that the method of linear aggregation assumes that there is no phenomenon of divergence or synergy between indicators and is suitable when indicators are having the same unit of measurement. It has the potential of compensability as compared to geometric aggregation, that is if some of the indicators have poor performance the effect is compensated by a high performance by other indicators, whereas geometric aggregation rewards more value to the index value for the countries having a higher score of indicators. Jollands (2003) explains that for increasing-scale indicators, linearweighted-sum aggregation is the most suited option.

To construct the one-dimensional index of social inclusion, this study considers four indicators. The first indicator is education and net school enrolment at the primary and secondary level from World Development Indicators (WDI) is used to measure the extent of individuals who are educated. It is measured as the proportion of children of school age enrolled in schools to the number of children of the corresponding official school-age. To gauge the level of health facilities received by individuals and thus their health position, life expectancy at birth rate have been used. It measures the expected number of years lived by a new-born infant if the mortality rate at the time of birth remains the same. To assess the level of social protection provided by the government to the households, data on public social protection expenditures as a percentage of GDP is used which is published by International Labour Organization (ILO) in coordination with Asian Development Bank (ADB) and other organizations.

To assess the level of equality among males and females in an economy, UNDP calculates the gender inequality index. It measures inequality across gender in the three aspects of human development that is, health (the indicators are maternal mortality ratio and adolescent birth rates), empowerment (the indicators used are the proportion of seats in the parliament occupied by female candidates and the ratio of female to male aged twenty-five years and above with at least secondary education) and economic status (measured as the ratio of female to male aged 15 and above having participation in the labour force). The higher value of the gender inequality index shows more inequality across gender that affect social inclusion adversely therefore its inverse is taken as a measure of gender equality. All the variables are normalized using a max-min approach, which is how the values of each indicator are ensured to be between 0 and 100. Since PCA assumes a sufficient level of correlation among indicators, a pairwise correlation and Bonferroni-adjusted level of a significance test are used. ${ }^{1}$

\subsection{Research Methodology}

Fiscal and monetary policy can affect both the income and non-income dimensions of wellbeing. Balakrishnan et al. (2011) give details that there is a need to operate fiscal and monetary policy in a way that mobilizes enough resources and directs them to finance socially productive ends. Thus, the current study attempts to see the composite impact of macroeconomic policies on social inclusion in developing countries. To assess the impact of macroeconomic policies on social inclusion, the following log-linear model has been formulated.

$$
\mathrm{SII}_{\mathrm{it}}=\beta_{1}+\beta_{2} \mathrm{M}_{\mathrm{it}}+\beta_{3} \mathrm{~F}_{\mathrm{it}}+\beta_{4} \mathrm{M}_{\mathrm{it}} \cdot \mathrm{F}_{\mathrm{it}}+\beta^{\prime}{ }_{5} \mathrm{Z}_{\mathrm{it}}+\mathrm{v}_{\mathrm{i}}+\omega_{\mathrm{t}}+\mathrm{u}_{\mathrm{it}}
$$


Through government expenditure, the state provides social goods and services to the vulnerable section of the society and taxes are a major source of financing the social goods in developing countries. Where SII is an index of social inclusion, $\mathrm{M}$ is money supply, F is fiscal policy ${ }^{2}$, and $\mathrm{Z}$ is the vector of control variables including capital, human capital, institutional quality, and trade. $\boldsymbol{u}$ is the error term and is assumed to be independently and identically distributed. The subscript $i$ is used to indicate the country and $t$ shows the time. The $v_{i}$ and $\omega_{t}$ show crosscountry and cross-time effects. The multiplicative interaction term $\left(\mathrm{M}^{*} \mathrm{~F}\right)$ is introduced in the model because fiscal policy and monetary policy are not independent. The effect of fiscal and monetary policy (from equation 1) are explained in the equations 2 and 3 below which shows the conditional impacts of monetary and fiscal policy on the social inclusion index respectively.

$$
\begin{aligned}
& \frac{\partial S I I}{\partial M}=\beta_{2}+\beta_{4} F \\
& \frac{\partial S I I}{\partial F}=\beta_{3}+\beta_{4} M
\end{aligned}
$$

The study considered a panel of 51 developing countries for the period 1995-2017 and employed pooled, fixed-effect, and random-effect methods of estimation. The fixed-effect model with country-specific intercept is used to control unobserved heterogeneity while the heterogeneity is assumed to be constant over time and is correlated with regressors. In the random-effects model, it is assumed that the cross-section effects are not correlated with the explanatory variables. To determine whether to use a random-effect or fixed-effect, the Hausman test is performed. To handle the issue of endogeneity and robustness, the two-stage least squares (2SLS) method has also been used. Further, to check the validity of instruments, Hansen's $J$ test, underlying the null hypothesis of "instruments are valid," is used.

\subsection{Description of Variables}

To measure social inclusion, this study considers the non-income dimensions of social wellbeing, that is, education, health, social protection, and gender equality, and constructs an index of social inclusion using PCA. The fiscal tools that are used in this study for analysis are government expenditure and tax revenue as a percentage of GDP. To capture the impact of money supply on social inclusion, the World Bank's data on broad money as a percentage of GDP is used. The control variables are capital stock, human capital trade, and institutional quality. For capital stock, gross fixed capital formation as a percentage of GDP is taken. Trade openness is calculated as the sum of imports and exports of goods and services divided by GDP. The data on the human capital index is based on years of schooling and returns to education is obtained from Federal Reserve Economic Data (FRED). Carter (2015) defines the inclusive institutions as the institutions that focus on providing equal opportunities and eliminates discrimination and target actions. Data on the institutional quality is gathered from the International Country Risk Guide (ICRG).

To handle the problem of missing data, this study takes different measures. The first measure is to exclude the countries for which over the required period, less than 25 percent of data is available (Lin et al., 2019). This leaves us with only 51 developing countries. To impute data, missing values of the variables showing linear trend have been predicted using a linear interpolation method and this treatment has been done for social protection expenditures and gender inequality index. For school enrolment, following the study of Gygli et al. (2019), the backward fill-in method is used. 


\section{Results and Discussion}

Table 1(a) explains the impact of government expenditures on social inclusion. Results show that the impact of control variables: human capital, institutional quality, and capital is positive and significant on social inclusion. Pogue and Sgontz (1977) are of the view that investment in human capital helps to reduce the social barriers and increases social security and thus helps to further improve the system of health and education system. Di-Cataldo and Rodríguez-Pose (2017) also find human capital to be an important factor that promotes social inclusion. On the other hand, about the view of Worlu and Nkoro (2012) -- the cause of underdevelopment of countries-- it is believed that corruption-prone environment in developing countries and lack of implementation of rule and regulation is the cause of underdevelopment of many countries thus the result shed light on the importance of institutional quality. The impact of trade on social inclusion is negative in the case of pooled OLS (POLS hereafter) and 2SLS, whereas insignificant in the case of Fixed Effects Model (FEM) and Random Effects Model (REM).

The linear term of government expenditure $(\mathrm{G})$ has a positive significant coefficient, whereas the coefficient of the quadratic term is negative and significant. To analyse the impact of government expenditure, a derivative concerning government expenditure has been taken and the effect is analysed assuming different levels of government expenditures.

$$
\begin{gathered}
S I I_{i t}=\alpha_{0}+\alpha_{1} G_{i t}+\alpha_{2} G_{i t}^{2}+\alpha_{3} Z_{i t}+u_{i t} \\
\frac{\partial S I I}{\partial G}=\alpha_{1}+2 . \alpha_{2} G
\end{gathered}
$$

\begin{tabular}{|c|c|c|c|c|}
\hline Variables & POLS & FEM & REM & 2SLS \\
\hline $\mathrm{G}$ & $0.316^{* * *}(0.00)$ & $0.628^{* *} \quad(0.01)$ & $0.616^{* * *}(0.00)$ & $2.646 * * \quad(0.02)$ \\
\hline $\mathrm{G} 2$ & $-0.053 * * \quad(0.01)$ & $-0.139 * *(0.01)$ & $-0.135 * * *(0.01)$ & $-0.520 * * \quad(0.03)$ \\
\hline $\mathrm{HCI}$ & $0.954 * * *(0.00)$ & $1.383 \quad(0.102)$ & $(0.102)$ & $0.755^{* * *}(0.00)$ \\
\hline IQ & $0.178 * * *(0.00)$ & $0.072 * * *(0.00)$ & $0.071 * * *(0.00)$ & $0.123 * * \quad(0.04)$ \\
\hline $\mathrm{K}$ & $0.182 * * *(0.00)$ & $0.134 * * * \quad(0.00)$ & $0.135 * * * \quad(0.00)$ & $0.233 * * *(0.00)$ \\
\hline Trade & $-0.134 * * *(0.00)$ & & & $-0.154 * * *(0.00)$ \\
\hline Constant & $-1.786 * * *(0.00)$ & $-4.236 * * *(0.00)$ & $-3.981 * * *(0.00)$ & $-3.431 * * *(0.00)$ \\
\hline No. of obs. & 1147 & 1147 & 1147 & 896 \\
\hline No. of countries & 51 & 51 & 51 & 51 \\
\hline No. of instruments & & & & 12 \\
\hline R-Square & 0.697 & 0.615 & 0.641 & 0.567 \\
\hline F-Stats & 527.73 & 29.7 & 189.24 & 206.3 \\
\hline Hausman Test & & $23.666 * * *(0.00)$ & & \\
\hline $\begin{array}{l}\text { Hansen J Stat } \\
\text { (p-value) }\end{array}$ & & & & $(0.218)$ \\
\hline $\begin{array}{l}\text { Notes: The depende } \\
\text { GDP whereas G2 is } \\
\text { (Human capital ind } \\
\text { suggests that FEM } \\
\text { parentheses. } * \text {. }\end{array}$ & $\begin{array}{l}\text { riable is the index } \\
\text { quare of governm } \\
\text { K (Capital), IQ } \\
\text { erable and the Ha } \\
10,5 \text {, and } 1 \text { per }\end{array}$ & $\begin{array}{l}\text { Social inclusion } \\
\text { spending as a per } \\
\text { titutional Quality } \\
n-J \text { test suggests } \\
\text { t level of signific }\end{array}$ & $\begin{array}{l}\text { government spen } \\
\text { ge of GDP. The c } \\
\text { Trade (Trade of } \\
\text { struments are val } \\
\text { espectively. }\end{array}$ & $\begin{array}{l}\text { g as a percentage of } \\
\text { ol variables are HCI } \\
\text { ness). Hausman test } \\
\text {--values are given in }\end{array}$ \\
\hline
\end{tabular}

Table 1(a): Impact of Government Expenditures on Social Inclusion

The results of POLS and 2SLS in table-1(b) show that at low levels, government expenditures affect social inclusiveness positively and significantly but the value of the coefficient is 
declined when government expenditures are at a median level; whereas the impact of a high level of government expenditures turns out to be insignificant. This result is consistent with the study of Dollar and Kraay (2002) that suggests that an increase in overall government expenditures has an insignificant impact on education and health. However, since in developing countries productive expenditures get a lower share in overall government consumption expenditures, an increase in government expenditure just causes demand-pull inflation that makes access to education and health more expensive, thus about the study of Paternostro, Rajaram and Tiongson (2007) composition of government expenditure plays a big role in targeting the objectives such as economic growth, equity, and social indicators.

Table 1(b): Conditional Impact of Government Expenditures on Social Inclusion

\begin{tabular}{lllllll}
\hline GOVT & \multicolumn{1}{c}{ POLS } & \multicolumn{2}{c}{ FEM } & \multicolumn{2}{c}{ REM } & \multicolumn{2}{c}{ 2SLS } \\
\hline P25 & $0.673^{* * *}(0.000)$ & $0.023(0.672)$ & $-0.016(0.765)$ & $0.241^{* * *}(0.001)$ \\
\hline P50 & $0.045^{* *}(0.010)$ & $-0.079(0.260)$ & $-0.071(0.302)$ & 0.031 & $(0.400)$ \\
\hline P75 & 0.022 & $(0.361)$ & $-0.141(0.124)$ & $-0.130(0.144)$ & -0.196 & $(0.136)$ \\
\hline
\end{tabular}

Notes: *,**,*** are 10, 5, and 1 percent level of significance respectively. P25, P50, and P75 are the $25^{\text {th }}, 50^{\text {th }}$ and $75^{\text {th }}$ percentiles respectively.

The table- 2 explains the role of tax revenue in achieving social inclusiveness. Results indicate that all of the variables are having a positive and significant impact on social inclusion except trade openness which carries a negative and significant coefficient value in the case of POLS and 2SLS and insignificant in the case of REM and FEM.

Table 2: Impact of Taxes on Social Inclusion

\begin{tabular}{|c|c|c|c|c|}
\hline Variables & POLS & FEM & REM & $2 \mathrm{SLS}$ \\
\hline $\mathrm{TX}$ & $0.063^{* * *}(0.00)$ & $(0.79)$ & $(0.785)$ & $0.080^{* * *}(0.00)$ \\
\hline HCI & $0.965 * * *(0.00)$ & $1.394 * * *(0.00)$ & $1.346 * * *(0.00)$ & $0.778 * * *(0.00)$ \\
\hline IQ & $0.168 * * *(0.00)$ & $0.114 * * \quad(0.04)$ & $0.108 * * \quad(0.03)$ & $0.166^{* * *}(0.00)$ \\
\hline $\mathrm{K}$ & $0.178 * * *(0.00)$ & $0.115 * * \quad(0.04)$ & $0.118 * * \quad(0.03)$ & $0.331 * * *(0.00)$ \\
\hline Trade & $-0.144 * * *(0.00)$ & & & $-0.133 * * *(0.00)$ \\
\hline Constant & $-1.464 * * *(0.00)$ & $-3.803 * * *(0.00)$ & $-3.525^{* * *}(0.00)$ & $-0.911 * * *(0.00)$ \\
\hline No. of obs. & 1147 & 1147 & 1147 & 696 \\
\hline No. of countries & 51 & 51 & 51 & 51 \\
\hline No. of instruments & & & & 15 \\
\hline R-Square & 0.657 & 0.649 & 0.65 & 0.65 \\
\hline F-stat & $34.231 \quad(0.00)$ & 10.141 & & 379.622 \\
\hline Hausman Test & & $(0.00)$ & & \\
\hline $\begin{array}{l}\text { Hansen J Stat } \\
\text { (p-value) }\end{array}$ & & & & $(0.133)$ \\
\hline
\end{tabular}

Notes: As for Table1 except that TX is tax revenue. Hausman test suggests that FEM is preferable however; REM is still used to see the effects of policies on the dependent variable after controlling random effects.

Tax revenue has a positive effect on social inclusion because, in developing countries, the government depends heavily on tax revenue to provide public goods. Owolabi and Okwu (2011) conclude that tax revenue has a positive effect on infrastructure, education, health, and social development. The provision of these public goods helps the socially disadvantaged group, that is, women and low-income groups to have opportunities to be part of society. Public provision of education and health services affects the well-being of women because most of the women are engaged in the provision of public services. Thus, an effective tax system can create a fiscal space to address gender inequality (Grown \& Valodia, 2010). 
The results of the model explaining the impact of money supply on social inclusion are reported in table-3. According to FEM and REM, money supply, institutional quality, and human capital have a positive significant impact on social inclusiveness whereas trade and capital formation do not show any impact on social inclusion. The results of POLS show that the control variables: human capital, institutional quality, and capital formation have a positive and significant impact on social inclusion, whereas trade is affecting social inclusion negatively. According to the 2SLS results, trade does not have any significant impact on social inclusion whereas other variables have a positive effect on social inclusion. The money supply is observed to be affecting social inclusion in all of the four models. According to Ihsan and Anjum (2013) a sound monetary policy devised by the central bank, through credit availability, can ensure an inclusive health and education system. In developing countries, at the time of lack of resources, money supply through seigniorage helps the government to finance social goods. On the other hand, an increase in the supply of money makes the interest rate low that in turn encourages private and public investment in all sectors including health and education.

Table 3: Impact of Money Supply on Social Inclusion

\begin{tabular}{|c|c|c|c|c|}
\hline Variables & POLS & FEM & REM & 2SLS \\
\hline $\mathrm{M}$ & $0.163 * * *(0.00)$ & $0.172 * * *(0.00)$ & $0.177 * * *(0.00)$ & $0.126 * * *(0.00)$ \\
\hline $\mathrm{HCI}$ & $0.887 * * *(0.00)$ & $1.082 * * *(0.00)$ & $1.043 * * *(0.00)$ & $0.724 * * *(0.00)$ \\
\hline IQ & $0.116^{* * *}(0.00)$ & $0.124 * * *(0.00)$ & $0.118^{* * *}(0.00)$ & $0.146^{* * *}(0.00)$ \\
\hline $\mathrm{K}$ & $0.094 * * *(0.00)$ & & & $0.147 * * *(0.00)$ \\
\hline Trade & $-0.126 * * *(0.00)$ & & & \\
\hline Constant & $-1.068^{* * *}(0.00)$ & $-2.419 * * *(0.01)$ & $-2.201 * * *(0.00)$ & $-0.855^{* * *}(0.00)$ \\
\hline No. of obs. & 1147 & 1147 & 1147 & 696 \\
\hline No. of countries & 51 & 51 & 51 & 51 \\
\hline No. of instruments & & & & 15 \\
\hline R-Square & 0.748 & 0.634 & 0.714 & 0.71 \\
\hline F-Stat & $(0.00)$ & $(0.00)$ & & 483.53 \\
\hline Hausman Test & & $(0.03)$ & & \\
\hline $\begin{array}{l}\text { Hansen J Stat } \\
\text { (p-value) }\end{array}$ & & & & $(0.131)$ \\
\hline
\end{tabular}

Notes: As for table-1 except that, $\mathrm{M}$ is the money supply.

To analyse the interactive role of money supply $(\mathrm{M})$ and government expenditures $(\mathrm{G})$ on social inclusion, models in table-4(a) include along with control variables, money supply, government consumption, and their interactive term. Results show that in all the four models, the control variable human capital affects social inclusion positively, whereas except in 2SLS, the impact of capital formation (investment) is positive and significant. POLS and 2SLS results show that institutional quality has a positive and significant impact on social inclusion whereas trade openness has a significantly negative impact on the dependent variable in the case of POLS. To analyse the impact of money supply and government expenditures, a derivative of the model has been taken concerning government expenditures and money supply given as follows.

$$
\begin{gathered}
S I I_{i t}=\beta_{0}+\beta_{1} M_{i t}+\beta_{2} G_{i t}+\beta_{3} G_{i t}^{2}+\beta_{4} M \cdot G_{i t}+\beta_{5} M \cdot G_{i t}^{2}+\beta_{6} Z_{i t}+u_{i t} \\
\frac{\partial S I I}{\partial M}=\beta_{1}+\beta_{4} G_{i t}+\beta_{5} \cdot G^{2} \\
\frac{\partial S I I}{\partial G}=\beta_{2}+\beta_{3 .} 2 \cdot G_{i t}+\beta_{4} \cdot M_{i t}+\beta_{5} \cdot 2 \cdot M \cdot G_{i t}
\end{gathered}
$$


Table 4(a): Interactive effects of Money Supply and Govt. Expenditures on SII

\begin{tabular}{|c|c|c|c|c|}
\hline Variables & POLS & FEM & REM & 2SLS \\
\hline Money & $0.323 * * \quad(0.02)$ & $(0.372)$ & 0.188 & $0.790 * * \quad(0.00)$ \\
\hline $\mathrm{G}$ & $1.102 * * *(0.01)$ & $1.322 * * \quad(0.04)$ & $1.311 * * \quad(0.04)$ & $2.511 * * *(0.00)$ \\
\hline $\mathrm{G} 2$ & $-0.275^{* * *}(0.00)$ & $-0.375^{* *}(0.03)$ & $-0.372 * *(0.02)$ & $-0.579 * * *(0.00)$ \\
\hline $\mathrm{M}^{*} \mathrm{G}$ & $-0.219^{*} \quad(0.06)$ & $-0.167 \quad(0.38)$ & $-0.166 \quad(0.379)$ & $-0.620 * * *(0.01)$ \\
\hline $\mathrm{M} * \mathrm{G} 2$ & $0.059 * * *(0.01)$ & $(0.19)$ & $(0.17)$ & $0.140 * \quad(0.00)$ \\
\hline HCI & $0.853 * * *(0.00)$ & $1.028 * * *(0.00)$ & $1.003 * * *(0.00)$ & $0.800 * * *(0.00)$ \\
\hline IQ & $0.105 * * *(0.00)$ & & & $0.111 * * *(0.00)$ \\
\hline $\mathrm{K}$ & $0.107 * * *(0.00)$ & $0.120 * * *(0.00)$ & $0.119 * * *(0.00)$ & \\
\hline Trade & $-0.125^{* * *}(0.00)$ & & & \\
\hline Constant & $-1.861 * * *(0.00)$ & $-2.744 * * *(0.01)$ & $-2.617 * * *(0.00)$ & $-3.42 * * * \quad(0.00)$ \\
\hline No. of obs. & 1147 & 1147 & 1147 & 1096 \\
\hline No. of countries & 51 & 51 & 51 & 51 \\
\hline No. of instrumen & & & & 9 \\
\hline R-Square & 0.754 & 0.68 & 0.71 & 0.72 \\
\hline F-Stats & 434.25 & 23.46 & 181.44 & 433.24 \\
\hline Hausman Test & & $(0.665)$ & & \\
\hline $\begin{array}{l}\text { Hansen J Stat } \\
\text { (p-value) }\end{array}$ & & & & 2.395 \\
\hline
\end{tabular}

Notes: As for table-1 except that $M * G$ is the interaction of money supply and government spending and $M * G 2$ is the interaction of money supply with squared government spending.

The final impact of money supply and government expenditures is analysed assuming different levels of government expenditures and money supply. Table-4(b) shows the impact of money supply and the results indicate that money supply affects social inclusion at all levels of government expenditures, while at higher government expenditures, money supply through the printing of money finances the expenditures of government on education, health and social protection and thus improve social inclusiveness.

Table 4(b): Impact of Money Supply Given Government Spending Levels

\begin{tabular}{lcllc}
\hline GOVT & POLS & \multicolumn{1}{c}{ FEM } & \multicolumn{1}{c}{ REM } & 2SLS \\
\hline P25 & $0.139^{* * *}(0.00)$ & $0.120^{* * *}(0.002)$ & $0.124^{* * *}(0.001)$ & $0.145^{* * *}(0.00)$ \\
\hline P50 & $0.154^{* * *}(0.00)$ & $0.146^{* * *}(0.00)$ & $0.149^{* * *}(0.00)$ & $0.163^{* * *}(0.00)$ \\
\hline P75 & $0.176^{* * *}(0.00)$ & $0.178^{* * *}(0.00)$ & $0.182^{* * *}(0.00)$ & $0.196^{* * *}(0.00)$ \\
\hline
\end{tabular}

Notes: As for table-1(a).

The result in table-4(c) shows the effect of government expenditures on the social inclusion of inclusive growth. When the government expenditure is set at the $25^{\text {th }}$ percentile, Pooled OLS shows a positive and significant impact on social inclusion at all levels of money supply while FEM and REM show an insignificant impact. On the other hand, 2SLS shows that at awer money supply, the effect of the government expenditure is insignificant and at a higher money supply, the effect of the government expenditures at the $25^{\text {th }}$ percentile affects social inclusion significantly and positively. If the government expenditure is set at the median level, the results of FEM, REM, and 2SLS show that if the money supply is less than the median level, the government expenditure affects the social inclusion negatively while at a higher money supply, it affects the social inclusion positively. Setting the government expenditures at high levels yield positive results if the money supply is also on a higher level because a higher money supply decreases the cost of borrowing and encourages the government to invest in human and social development. 
Table 4(c): Impact of Government Expenditures Given Money Supply Levels

\begin{tabular}{|c|c|c|c|c|}
\hline Money & POLS & FEM & REM & 2SLS \\
\hline \multicolumn{5}{|c|}{$\mathrm{G}=\mathrm{P} 25$} \\
\hline $\mathrm{P} 25$ & $0.029 * * \quad(0.036)$ & $\begin{array}{ll}-0.473 & (0.392) \\
\end{array}$ & $(0.421)$ & $(0.657)$ \\
\hline P50 & $0.052 * * *(0.00)$ & $\begin{array}{ll}-0.007 & (0.892)\end{array}$ & $(0.962)$ & $(0.296)$ \\
\hline $\mathrm{P} 75$ & $0.071 * * *(0.00)$ & $(0.595)$ & $(0.526)$ & $0.033 * * \quad(0.033)$ \\
\hline \multicolumn{5}{|c|}{$\mathrm{G}=\mathrm{P} 50$} \\
\hline $\mathrm{P} 25$ & $(0.918)$ & $-0.116^{*}(0.070)$ & $(0.071)$ & $-0.039 * *(0.042)$ \\
\hline P50 & $0.032 * * \quad(0.013)$ & $\begin{array}{ll}-0.067 & (0.205) \\
\end{array}$ & $(0.225)$ & $0.0027 \quad(0.849)$ \\
\hline $\mathrm{P} 75$ & $0.060 * * *(0.00)$ & $(0.630)$ & $(0.706)$ & $0.041 * * *(0.004)$ \\
\hline \multicolumn{5}{|c|}{$\mathrm{G}=\mathrm{P} 75$} \\
\hline $\mathrm{P} 25$ & $(0.215)$ & $(0.108)$ & $(0.171)$ & $-0.750 * * *(0.007)$ \\
\hline P50 & $-0.012 * *(0.012)$ & $-0.113 * *(0.041)$ & $-0.115 * *(0.043)$ & $(0.636)$ \\
\hline P75 & $0.048^{* * *}(0.006)$ & $0.081^{*} \quad(0.081)$ & $0.053 * * \quad(0.036)$ & $0.048 * * \quad(0.013)$ \\
\hline
\end{tabular}

Notes: As for table-1(a).

The interactive role of money supply and tax revenue on social inclusion is demonstrated in table-5(a). Regarding control variables, the results of POLS show that human capital, institutional quality, and capital formation have a positive and significant impact, whereas trade hurts social inclusion. Results of FEM and REM models show that the role of trade in determining social inclusiveness is insignificant, whereas 2SLS assumes only human capital and institutional quality as control variables and finds a positive and significant impact on social inclusion. To analyse the final impact of money supply given different levels of tax revenue and the effect of tax revenue given different levels of money supply, derivatives of the above model have been taken for money supply and tax revenue.

$$
\begin{array}{ccc}
S I I_{i t}=\gamma_{0}+\gamma_{1} M_{i t}+\gamma_{2} T X_{i t}+\gamma_{3} M . T X_{i t}+\gamma_{4} Z_{i t}+u_{i t} \\
\frac{\partial S I I}{\partial M}=\gamma_{1}+\gamma_{3} T X_{i t} & \text { and } & \frac{\partial S I I}{\partial T X}=\gamma_{2}+\gamma_{3 .} M_{i t}
\end{array}
$$

\begin{tabular}{|c|c|c|c|c|}
\hline Variables & POLS & FEM & REM & 2SLS \\
\hline $\mathrm{M}$ & $0.169^{* * *}(0.00)$ & $0.169^{* *} \quad(0.03)$ & $0.173^{* * *}(0.01)$ & $0.479 * * *(0.00)$ \\
\hline TX & $\begin{array}{ll}0.033 & (0.37)\end{array}$ & $\begin{array}{ll}-0.008 & (0.93)\end{array}$ & -0.008 & 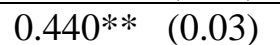 \\
\hline $\mathrm{TX}^{*} \mathrm{M}$ & $\begin{array}{ll}-0.003 & (0.72) \\
\end{array}$ & -0.004 & -0.004 & $-0.127 * *(0.01)$ \\
\hline $\mathrm{HCI}$ & $0.885^{* * *}(0.00)$ & $1.074 * * *(0.00)$ & $1.043^{* * *}(0.00)$ & $0.784 * * *(0.00)$ \\
\hline IQ & $0.107 * * *(0.00)$ & $0.104 * * \quad(0.06)$ & $0.100 * * \quad(0.048)$ & $0.152 * * *(0.00)$ \\
\hline $\mathrm{K}$ & $0.097 * * *(0.00)$ & $0.096^{*}$ & $0.096^{*}$ & \\
\hline Trade & $-0.132 * * *(0.00)$ & & & \\
\hline Constant & $-1.075^{* * *}(0.00)$ & $-2.507 * * *(0.00)$ & $-2.334 * * *(0.00)$ & $-1.975 * * *(0.00)$ \\
\hline No. of obs. & 1147 & 1147 & 1147 & 897 \\
\hline No. of countries & 51 & 51 & 51 & 51 \\
\hline No. of instruments & & & & 14 \\
\hline R-Square & 0.748 & 0.72 & 0.718 & 0.70 \\
\hline F-Stat & 593.320 & 21.761 & 158.090 & 399.777 \\
\hline Hausman Test & & $(0.615)$ & & \\
\hline $\begin{array}{l}\text { Hansen J Stat } \\
\text { (p-value) }\end{array}$ & & & & $(0.13)$ \\
\hline
\end{tabular}

Table 5(a): Impact of Taxes and Money Supply on Social Inclusion 
The table-5(b) demonstrates the impact of money supply, given different levels of tax revenue, on social inclusion. Results indicate that the money supply affects social inclusion positively and significantly at all levels of tax revenue. A higher level of taxes creates distortionary effects in the economy because due to high taxation, workers get discouraged. On the other hand, a high tax rate on goods and services affects an individual's decision of saving and investment that in turn makes the poor section discourage investment in health and education. Therefore, the positive effect of money supply on social inclusion reduces with the increase in tax revenue.

Table 5(b): Impact of Money Supply Given Tax Revenue Levels

\begin{tabular}{lcccc}
\hline Tax Revenue & POLS & FEM & REM & 2SLS \\
\hline P25 & $0.161^{* * *}(0.00)$ & $0.160^{* * *}(0.002)$ & $0.164^{* * *}(0.001)$ & $0.174^{* * *}(0.00)$ \\
\hline P50 & $0.160^{* * *}(0.00)$ & $0.159^{* * *}(0.002)$ & $0.163^{* * *}(0.001)$ & $0.140^{* * *}(0.00)$ \\
\hline P75 & $0.159^{* * *}(0.00)$ & $0.158^{* * *}(0.003)$ & $0.162^{* * *}(0.001)$ & $0.105^{* * *}(0.00)$ \\
\hline
\end{tabular}

Notes: $* * *, * * * *$ are 1,5 , and 10 percent level of significance respectively. P25, P50, and P75 are the $25^{\text {th }}, 50^{\text {th }}$, and $75^{\text {th }}$ percentiles.

The table-5(c) shows the impact of tax revenues on the social inclusion of inclusive growth given different levels of the money supply. Results of FEM, REM, and POLS models indicate an insignificant role of tax revenue on social inclusion, whereas 2SLS results show that with a low level of money supply (at $25^{\text {th }}$ percentile) there is no impact of tax revenue on social inclusiveness; whereas given higher levels of money supply, increase in tax revenue leads to affect social inclusion adversely because inflationary pressure created by excess money supply makes the socially neglected groups worse-off.

Table 5(c): Impact of Tax Revenue Given Money Supply Levels

\begin{tabular}{lcclll}
\hline Money Supply & POLS & FEM & \multicolumn{2}{c}{ REM } & \multicolumn{2}{c}{ 2SLS } \\
\hline P25 & $0.031(0.103)$ & $-0.019(0.751)$ & $-0.021(0.720)$ & 0.001 & $(0.94)$ \\
\hline P50 & $0.020(0.129)$ & $-0.021(0.748)$ & $-0.022(0.714)$ & $-0.044^{* *}$ & $(0.014)$ \\
\hline P75 & $0.019(0.167)$ & $-0.022(0.748)$ & $-0.023(0.713)$ & $-0.086^{* * * *}(0.000)$ \\
\hline
\end{tabular}

Notes: ***,**, $*$ are 1,5 , and 10 percent levels of significance respectively. P25, P50, and P75 are the $25^{\text {th }}$, $50^{\text {th, }}$ and $75^{\text {th }}$ percentiles respectively.

Overall, the above results suggest that fiscal and monetary policy through resource mobilization can play a significant and positive role in promoting social inclusion. However, these fiscal and monetary policy actions are not independent. Thus, a policy mix is required to achieve the target of an inclusive society.

\section{Conclusion}

Based on results, we conclude that government expenditures promote social inclusiveness because the provision of public goods and services is the job of government, however high levels of expenditure do not affect social inclusiveness significantly, because, in the context of social welfare, it is the composition of the government expenditure that matters rather than the size. Tax revenue also affects social inclusion positively because tax revenue is the major source in developing countries to finance its spending. Expansionary monetary policy leads to an increase in socially inclusive growth because the interest rate and credit channel promote investment in education and health and encourages women entrepreneurs to invest by providing loans at a low-interest rate. Regarding the interactive role of the macroeconomic policies, the high levels of government expenditure combined with high levels of money supply help the government to provide social goods and thus affect social inclusion positively. Whereas 
effectiveness of money supply in improving social inclusion reduces conditional to a high level of tax collections while an increase in tax revenue given that economy is facing inflation associated with high money supply affects social inclusion negatively because already prevailing inflationary pressure created by excess money supply and distortionary effect of taxation combine makes the socially neglected groups worse-off.

Therefore, this study suggests that a country with low levels of social inclusiveness should be more focused on the composition of its government spending and tax structure. A higher proportion of spending on social goods and services makes individuals socially inclusive given the availability of resources. Relying on tax revenues only to finance government expenditures is not a good option for developing countries because these countries possess a regressive tax structure that affects the economic and social well-being of individuals unfavourably. There should be a debate on how these expenditures will be financed. However, this study also suggests that a corruption-free and strong institutional structure makes the policies properly implemented and helps to get the desired results.

\section{References}

Afonso, A., Alves, J., \& Balhote, R. (2019). Interactions between monetary and fiscal policies. Journal of Applied Economics, 22(1), 132-151. https://doi.org/10.1080/15140326.2019.1583309

Akram, M., \& Khan, F. J. (2007). Health care services and government spending in Pakistan (No. 2007: 32). Pakistan Institute of Development Economics. https://www.pide.org.pk/pdf/Working\%20Paper/WorkingPaper-32.pdf

Aslam, A., Naveed, A., \& Shabbir, G. (2020). Is it an institution, digital or social inclusion that matters for inclusive growth? A panel data analysis. Quality \& Quantity, 1-23. https://doi.org/10.1007/s11135-020-01008-3

Atkinson, A. B. (1998). Chapter one: Social exclusion, poverty, and unemployment. Centre for Analysis of Social Exclusion, CASE Paper, (4). https://gsdrc.org/documentlibrary/social-exclusion-poverty-and-unemployment/

Avramov, D. (2003). People, demography, and social exclusion: Population Studies, No. 37. Council of Europe. https://book.coe.int/en/population-studies-series/2686-peopledemography-and-social-exclusion-population-studies-no-37.html

Balakrishnan, R., Elson, D., Heintz, J., \& Lusiani, N. (2011). Maximum available resources and human rights. Centre for women's global leadership, Rutgers. The State University of New Jersey. https://repositorio.cepal.org/handle/11362/44322

Carter, B. (2015). Benefits to society of an inclusive societies approach. GSDRC Helpdesk Research Report 1232. GSDRC, University of Birmingham. https://gsdrc.org/publications/benefits-to-society-of-an-inclusive-societies-approach/

Ceano-Vivas, M.S., Rivera-Lirio, J. M., \& Munoz-Torres, M. (2014, November 10). The role of fiscal policy in the achievement of social cohesion. Tax Mix and Public Social Spending. https://dx.doi.org/10.2139/ssrn.2521328

Crotti, R., Geiger, T., Ratcheva, V. \& Zahidi, S. (2020). The global gender gap report 2020. World Economic Forum. https://www.weforum.org/reports/gender-gap-2020-report100 -years-pay-equality

De-la-Brière, B., \& Rawlings, L. B. (2006). Examining conditional cash transfer programs: A role for increased social inclusion? No. 90341. The World Bank. https://openknowledge.worldbank.org/handle/10986/20204 
Di Cataldo, M., \& Rodriguez-Pose, A. (2017). What drives employment growth and social inclusion in the regions of the European Union? Regional Studies, 51(12), 18401859. https://doi.org/10.1080/00343404.2016.1255320

Dollar, D., \& Kraay, A. (2002). Growth is good for the poor. Journal of Economic Growth, 7(3), 195-225. https://doi.org/10.1023/A:1020139631000

Drucza, K. (2016). Cash transfers in Nepal: Do they contribute to social inclusion?. Oxford Development Studies, 44(1), 49-69. https://doi.org/10.1080/13600818.2015.1065313

European Commission (2004). Public finance in EMU. Brussels. https://ec.europa.eu/economy_finance/publications/pages/publication469_en.pdf

Felder, F. (2018). The value of inclusion. Journal of Philosophy of Education, 52(1), 54-70. https://doi.org/10.1111/1467-9752.12280

Gradstein, M., \& Justman, M. (2002). Education, social cohesion, and economic growth. American Economic Review, 92(4), 1192-1204. https://doi.org/10.1257/00028280260344722

Grown, C., \& Valodia, I. (Eds.). (2010). Taxation and gender equity: a comparative analysis of direct and indirect taxes in developing and developed countries, Vol. 58, IDRC. https://doi.org/10.1080/13545701.2011.573489

Gygli, S., Haelg, F., Potrafke, N., \& Sturm, J.-E. (2019). The KOF globalisation indexrevisited. The Review of International Organizations, 14(3), 543-574. https://doi.org/10.1007/s11558-019-09344-2

Ihsan, I., \& Anjum, S. (2013). Impact of money supply (M2) on GDP of Pakistan. Global Journal of Management and Business Research, 13(6). https://journalofbusiness.org/index.php/GJMBR/article/view/999

Islam, M. Q. (2000). Fiscal policy and social welfare in selected MENA countries. In: Shahin, W. \& Dibeh, G. (Eds.) Earnings Inequality, Unemployment, and Poverty in the Middle East and North Africa. Greenwood.

Jollands, N. (2003). The usefulness of aggregate indicators in policy making and evaluation: a discussion with application to eco-efficiency indicators in New Zealand. Inaugural EEN (Economics and Environment Network) National Workshop, 1-3 May 2003, Canberra, ACT. https://openresearch-repository.anu.edu.au/handle/1885/41033

Kaiser, H. F. (1960). The application of electronic computers to factor analysis. Educational and Psychological Measurement, 20(1), 141-151. https://doi.org/10.1177\%2F001316446002000116

Klasen, S. (2010). Measuring and monitoring inclusive growth: Multiple definitions, open questions, and some constructive proposals. ADB Sustainable Development working paper series No. 12, Asian Development Bank. http://hdl.handle.net/11540/1404

Lin, J. Y., Monga, C., \& Standaert, S. (2019). The inclusive sustainable transformation index. Social Indicators Research, 143(1), 47-80. https://doi.org/10.1007/s11205-018-1977-1

Mooi, E., Sarstedt, M. and Mooi-Reci, I. (2018). Market research: The process, data, and methods using Stata. Heidelberg: Springer. https://doi.org/10.1111/1475-4932.12550

Nardo, M., Saisana, M., Saltelli, A., \& Tarantola, S. (2005). Tools for composite indicators building. European Comission, Ispra, 15(1), 19-20.

O'Brien, M., \& Penna, S. (2008). Social exclusion in Europe: Some conceptual issues. International Journal of Social Welfare, 17(1), 84-92. https://doi.org/10.1111/j.1468-2397.2006.00478.x

Oxoby, R. (2009). Understanding social inclusion, social cohesion, and social capital. International Journal of Social Economics,36(12), 1133-1152. https://doi.org/10.1108/03068290910996963 
Owolabi, S., \& Okwu, A. T. (2011). Empirical evaluation of contribution of value added tax to development of Lagos State economy. Middle Eastern Finance and Economics, 1(9), 24-34. http://www.eurojournals.com/MEFE.htm

Paternostro, S., Rajaram, A., \& Tiongson, E. R. (2007). How does the composition of public spending matter? Oxford Development Studies, 35(1), 47-82. https://doi.org/10.1596/1813-9450-3555

Pogue, T. F., \& Sgontz, L. G. (1977). Social security and investment in human capital. National Tax Journal, 157-169. https://www.jstor.org/stable/41862126

Ravenna, F., \& Walsh, C. (2010). The welfare consequences of monetary policy and the role of the labour market: A tax interpretation, No. 10-01. HEC Montreal, Institut d'economie appliquee. https://econpapers.repec.org/RePEc:lvl:lacicr:1028

Rawal, N. (2008). Social inclusion and exclusion: a review. Dhaulagiri Journal of Sociology and Anthropology, 2, 161-180. https://doi.org/10.3126/dsaj.v2i0.1362

Salzman, J. (2003). Methodological choices encountered in the construction of composite indices of economic and social well-being. Technical Report, Center for the Study of Living Standards, Ottawa. https://www.semanticscholar.org/paper/MethodologicalChoices-Encountered-in-the-of-of-and-

Salzman/5de2dfa32410291183108a2439ecb89ea7f51e66

Tangcharoensathien, V., Mills, A., Das, M. B., Patcharanarumol, W., Buntan, M., \& Johns, J. (2018). Addressing the health of vulnerable populations: Social inclusion and universal health coverage. Journal of Global Health, 8(2). https://dx.doi.org/10.7189\%2Fjogh.08.020304

UNESCO (2012). What role for UNESCO in 2014-2021? Consultations of the DG with Member States: Social Inclusion, Social Transformations, Social Innovation. https://www.unesco.org/new/fileadmin/multimedia/hq/bpi/epa/images/media_servic es/directorgeneral/conceptnotesocialinclusionsocialtransformationssocialinnovationen.pdf

Wan, G., \& Zhuang, J. (2015). Making growth more inclusive. In Managing the middle-income transition. Edward Elgar. https://doi.org/10.4337/9781783477708.00026

Wang, C., \& Naveed, A. (2019). The social inclusion and inequality nexus: EU versus non-EU migrants. International Migration, 57(3), 41-62. https://doi.org/10.1111/imig.12567

World Bank. (2006). Equity and development: world development report 2006. World Bank. http://documents1.worldbank.org/curated/en/435331468127174418/pdf/322040Wor ld0Development0Report02006.pdf

World Bank. (2011). Gender equality and development: world development report 2012. World Bank. https://doi.org/10.1111/j.1467-7660.2012.01743.x

World Bank. (2013). Inclusion matters: The foundation of shared prosperity. World Bank. http://documents.worldbank.org/curated/en/114561468154469371/Inclusionmatters-the-foundation-for-shared-prosperity

Worlu, C. N., \& Nkoro, E. (2012). Tax revenue and economic development in Nigeria: a macro econometric approach. Academic Journal of Interdisciplinary Studies, 1(2), 211-211. http://www.richtmann.org/journal/index.php/ajis/article/view/11650

\section{Notes:}

${ }^{1}$ Author can provide the results of PCA on demand.

${ }^{2}$ This study uses tools of fiscal policy, that is, government expenditures and tax revenue one by one in the model. 